\title{
Modern surface pollen assemblages from the Middle and High Atlas, Morocco: Insights into pollen representation and transport
}

DOI:

10.1080/00173134.2015.1108996

\section{Document Version}

Accepted author manuscript

Link to publication record in Manchester Research Explorer

Citation for published version (APA):

Bell, B., \& Fletcher, W. J. (2016). Modern surface pollen assemblages from the Middle and High Atlas, Morocco: Insights into pollen representation and transport. Grana, 55(4), 286-301.

https://doi.org/10.1080/00173134.2015.1108996

Published in:

Grana

\section{Citing this paper}

Please note that where the full-text provided on Manchester Research Explorer is the Author Accepted Manuscript or Proof version this may differ from the final Published version. If citing, it is advised that you check and use the publisher's definitive version.

\section{General rights}

Copyright and moral rights for the publications made accessible in the Research Explorer are retained by the authors and/or other copyright owners and it is a condition of accessing publications that users recognise and abide by the legal requirements associated with these rights.

\section{Takedown policy}

If you believe that this document breaches copyright please refer to the University of Manchester's Takedown Procedures [http://man.ac.uk/04Y6Bo] or contact uml.scholarlycommunications@manchester.ac.uk providing relevant details, so we can investigate your claim.

\section{OPEN ACCESS}


Author's Accepted Manuscript - Bell \& Fletcher (2016). Modern surface pollen assemblages from the Middle and High Atlas, Morocco: Insights into pollen representation and transport. Grana, 55:4, 286-301. Available online: https://doi.org/10.1080/00173134.2015.1108996

\title{
Title
}

Modern surface pollen assemblages from the Middle and High Atlas, Morocco: Insights into pollen representation and transport

\section{Authors}

Benjamin A. Bell ${ }^{1}$ and William J. Fletcher ${ }^{1}$

${ }^{1}$ Quaternary Environments and Geoarchaeology, Geography, School of Environment, Education and Development, The University of Manchester, Oxford Road, Manchester, M13 9PL, UK

\section{benjamin.bell@manchester.ac.uk, will.fletcher@manchester.ac.uk}

\begin{abstract}
33 modern surface samples were collected in the environmentally and climatologically contrasting regions of the Middle and High Atlas Mountains, Morocco. Samples representing forested and steppe montane environments (1935 m to $2760 \mathrm{~m}$ a.s.l.) are clustered around study sites at Lake Tislit (High Atlas, semi-arid oro-Mediterranean bioclime), and Lake Sidi Ali and Michliffen (Middle Atlas, sub-humid montane Mediterranean bioclime). Good discrimination between regional pollen spectra is evident, with Middle Atlas samples reflecting higher arboreal cover (Cedrus and evergreen Quercus) and High Atlas samples with high abundances of non-arboreal taxa, including Artemisia and Fabaceae. These four taxa (Cedrus, evergreen Quercus, Artemisia and Fabaceae) are furthermore shown to be reliable indicators of local source vegetation within a $100 \mathrm{~m}^{2}$ quadrat, taking into account threshold abundances of 7\%, 20\%, 4\% and 10\%, respectively. Deciduous Quercus, Olea and Phillyrea show long-distance pollen dispersal across both regions, contributing to non-trivial arboreal pollen (AP) values of up to $35 \%$ (typically $20-30 \%$ ) in the High Atlas spectra. In the Middle Atlas, AP values of $40-50 \%$ occur in open sampling locations and $>60 \%$ under forest canopy cover. These insights should be taken into account when interpreting ancient pollen spectra from regional lakes and bogs for palaeoenvironmental reconstruction.
\end{abstract}

\section{Keywords}

Modern pollen rain, pollen analysis, pollen dispersal, vegetation, montane environments, Cedrus atlantica, Correspondence Analysis, European Modern Pollen Database 
Author's Accepted Manuscript - Bell \& Fletcher (2016). Modern surface pollen assemblages from the Middle and High Atlas, Morocco: Insights into pollen representation and transport. Grana, 55:4, 286-301. Available online: https://doi.org/10.1080/00173134.2015.1108996

\section{Introduction}

Preservation of pollen and spores in sedimentary records provides a proxy of past environment, vegetation and climate. Challenges arise interpreting the pollen record due to differential pollen preservation, production and dispersal, as well as the physical characteristics of the sampling site making reconstructions difficult (Davis 1984; Birks \& Gordon 1985; Prentice 1985; Gaillard et al. 1994; Sugita 1994; Ritchie 1995; Hicks 2001). Understanding the relationships between modern vegetation and pollen assemblages is therefore imperative for the interpretation of fossil pollen and the reconstruction of paleoenvironments and climate (Wright 1967; Jackson and Williams 2004; Fall 2012). The use of modern surface samples can improve the understanding of under- and overrepresented taxa and the long-distant transport of pollen (Erdtman 1943; Faegri and Iversen 1950; Davis and Goodlett 1960; Bradshaw 1981; Bhattacharya et al. 2011). For example, in montane environments it is important to understand the altitudinal movement of pollen (Yu et al., 2001; Weng et al., 2004; Canellas-Bolta et al. 2009) and the influence of prevailing (Markgraf, 1980).

Morocco is a crucial area for the reconstruction of palaeoclimate change for the Maghreb (e.g Rognon 1987; Lamb et al. 1989). The region is sensitive to the effects of future climate change with increased temperatures, reduced precipitation and more frequent droughts predicted (Giorgi 2006; Born et al. 2008; Solomon et al. 2009). Climate change in the region has caused dieback of Cedrus atlantica across the Middle and High Atlas due to a rain deficit since the 1980s, especially in areas which are not ecologically optimum for the species (Rhanem 2011). Many parts of the Middle and High Atlas ranges are now near the climatological limits of forest development. The areas are also subject to intense anthropogenic activity through agriculture and grazing, causing further degradation to the landscape (Lamb et al. 1994; Barrow and Hicham 2000). Due to these climate and anthropogenic effects upon the forest it is important to understand the relationships between the abundance of arboreal pollen and tree cover in the pollen spectra. Therefore, insights from palaeoecology into the sensitivity and resilience of ecosystems as well as context provided by historical perspectives on environmental change are critical (Lamb et al. 1989; Lamb et al. 1991; Lamb et al. 1999)

In this paper we examine the modern pollen assemblages and vegetation relationships at three montane study sites: Lake Tislit in the High Atlas, and Lake Sidi Ali and Michliffen in the Middle Atlas. This study is based on an opportunistic sampling of surface soils $(n=33)$ undertaken near two lakes and one forest. The lakes (Tislit and Sidi Ali) were investigated in the context of bathymetric, seismic and hydrological surveys in 2012, leading to new multiproxy investigations of lake sediments. 
The knowledge of surface sample pollen spectra is therefore of particular interest for the interpretation of emerging new palaeoecological records. We also examine our results in the context of archived surface pollen data for the study region. The European Modern Pollen Database (Davis et al. 2013) contains a large dataset of unpublished surfaces samples from Morocco $(n=284)$, which has been previously used for quantitative climate reconstruction (e.g. Cheddadi et al. 1998). However, the lack of metadata on site and vegetation characteristics limits the value of this dataset in terms of further detailed evaluation of vegetation-pollen relationships. We also make reference to a published study (Saadi and Bernard 1991, henceforth SB91) of surface pollen spectra from Morocco $(n=73)$ for which geographical coordinates and brief vegetation notes are available.

The aims of the current study are to 1) characterise the typical pollen spectra at the three sites and explore the potential for discrimination of different regional vegetation cover types; 2 ) examine local variability in pollen spectra over small spatial scales; $3 a$ ) identify taxa that are good indicators of local presence and propose approximate threshold values for local presence; $3 b$ ) identify those taxa that are poor discriminators of local presence; and 3c) identify taxa that are representative of long-distance transport.

\section{Material and methods}

\section{Study areas}

The Atlas Mountains comprise the Middle (Moyen) Atlas, High (Haut) Atlas and Anti-Atlas ranges, covering the eastern, central, and southerly areas of the country respectively (Figure 1a). The regional climate alternates between wet and dry seasons influenced by polar air masses and subtropical high-pressure systems, respectively. In winter, North Atlantic westerlies bring cooler air and rain, while in summer the region experiences hotter temperatures and drought due to a combination of Atlantic (Azores) and Saharan high pressure systems (Fink et al. 2010). The climate of the Middle Atlas is relatively cool and humid compared with the High Atlas, and here the most extensive development of Cedrus atlantica (Endl.) Manetti ex Carrière is observed, alongside the evergreen Quercus rotundifolia Lam (syn. Quercus ilex subsp. ballota (Desf.) Samp.), with deciduous Quercus faginea Lam. and Quercus pyrenaica Willd. at lower altitudes (Emberger 1939; Quezel 2002). In the relatively drier and more continental High Atlas, the dominant vegetation cover is composed of Juniperus thurifera L. and steppic formations (e.g. Haroni 2009, Navarro et al. 2009) (Figure 1b). 

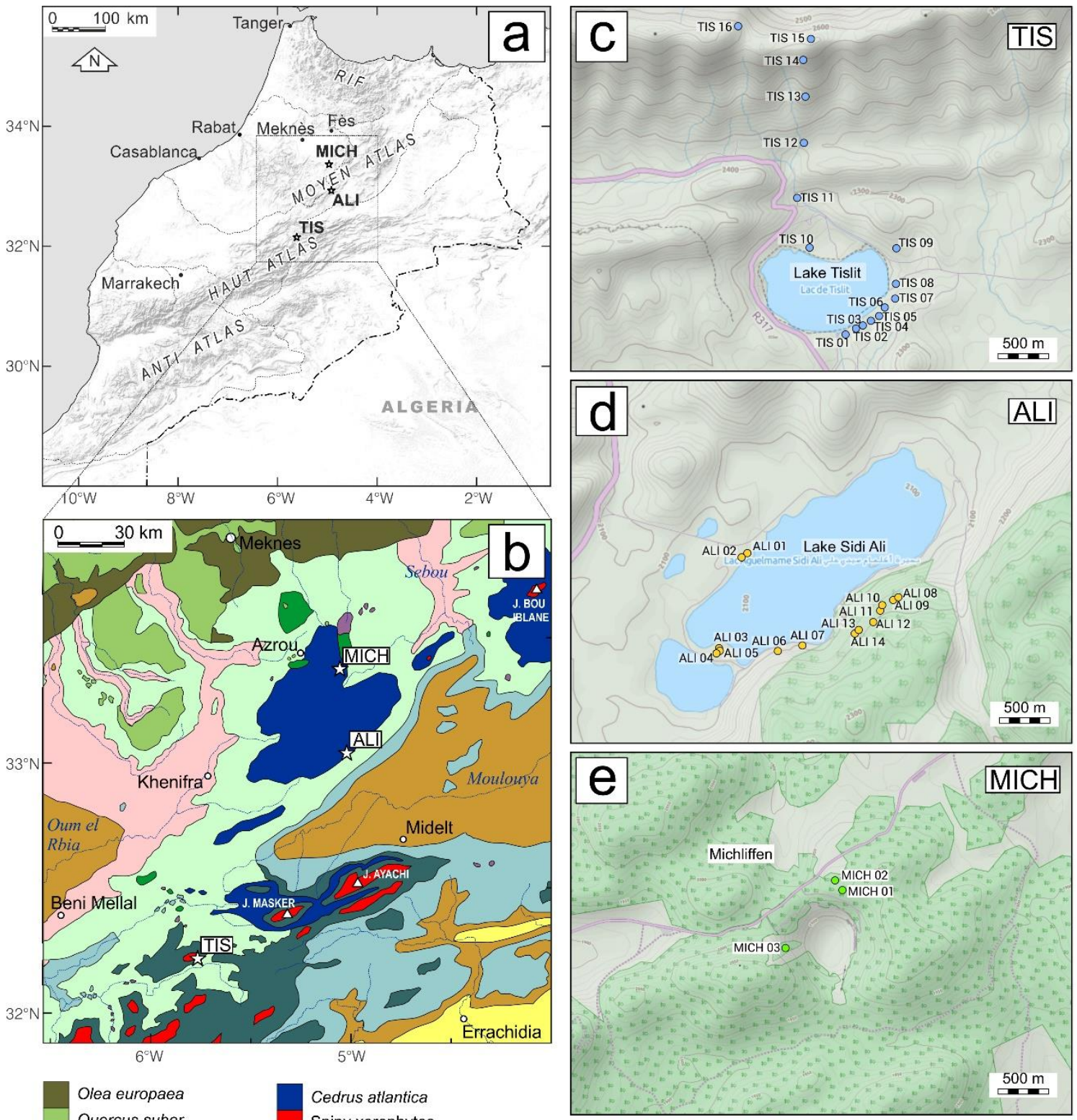
Quercus suber

Cedrus atlantica Spiny xerophytes

Juniperus thurifera

rotundifolia Juniperus phoenicea

Quercus faginea

Ziziphus, Pistacia, Artemisia

Tetraclinis articulata

Pinus halepensis

Saharan desertic

Figure 1. Location of study sites and sampling locations, and map of vegetation. A. Overview map of Morocco showing location of study sites. B. Map of dominant vegetation types for the study area based on Emberger (1939). C. Map of sample sites around Lake Tislit. D. Map of samples sites around Lake Sidi Ali. E. Map of sample sites at Michliffen. Map source: (c) OpenStreetMap contributors.

High Atlas Mountains: Lake Tislit (TIS). - The High Atlas study site (TIS) is located in the vicinity of Lake Tislit on the Plateau des Lacs, $4 \mathrm{~km}$ north of Imichil. Lake Tislit, located at $32^{\circ} 11^{\prime} \mathrm{N}, 5^{\circ} 38^{\prime} \mathrm{W}$, $2250 \mathrm{~m}$ a.s.l., is one of two large lakes of contested karstic/meteor impact origin (Ibhi et al. 2013; 
Author's Accepted Manuscript - Bell \& Fletcher (2016). Modern surface pollen assemblages from the Middle and High Atlas, Morocco: Insights into pollen representation and transport. Grana, 55:4, 286-301. Available online:

https://doi.org/10.1080/00173134.2015.1108996

Chaabout et al. 2013; Akdim 2015) lying west of the larger Lake Isli. It has an area of approximately $0.75 \mathrm{~km}^{2}$ and a depth of $16 \mathrm{~m}$. Mean annual precipitation recorded at nearby Imilchil is reported to be on the order of $244 \mathrm{~mm}$ to $319 \mathrm{~mm}$ with very high inter-annual variability (Peyron 1980; Lamb et al. 1994). Precipitation is characterised by intense rainstorms in spring and summer which cause flash floods and increase surface erosion in the area. Average maximum summer temperatures reach $30^{\circ} \mathrm{C}$, while winter minima average $-4^{\circ} \mathrm{C}$ (Lamb et al. 1994). The vegetation is characteristic of the oro-Mediterranean thorn cushion plant formations of the High Atlas (Navarro et al. 2009) consisting of sparse shrubs and a range of perennial herbs and grasses (Figure 2a-c). These include cushion-form spiny sub-shrubs such as Bupleurum spinosum Gouan and members of the Fabaceae family (Erinacea anthyllis Link, Cytisus spp., Astragalus spp.), accompanied by low-growing plants from Crassulaceae, Helianthemum spp. and Lamiaceae (Thymus spp.). Berberis hispanica Boiss. \& Reut. and Prunus prostrata Labill. develop in rocky crevices and gullies. There is considerable grazing pressure from sheep and goats. There is little to no tree cover in the immediate area, excluding occasional junipers (Juniperus thurifera) near the lake itself, and a few planted trees (Pinus halepensis Mill. and Populus sp.) around the western margin of the lake. Tree cover with Juniperus thurifera and Quercus rotundifolia is developed at around $20 \mathrm{~km}$ distance across the watershed to the northwest on Atlantic (north-west) facing slopes, and Cedrus forest is located around $40 \mathrm{~km}$ distance to the northeast on the slopes of Jbel Masker.

Middle Atlas Mountains: Lake Sidi Ali (ALI). - The first of two Middle Atlas study sites (ALI) is located in the vicinity of Lake Sidi Ali at $33^{\circ} 03^{\prime} \mathrm{N}, 5^{\circ} 00^{\prime} \mathrm{W}, 20 \mathrm{~km}$ south of Timahdite. It is one of the largest and highest altitude (2,080 m.a.s.I.) lakes in the Middle Atlas, located towards the southeastern limits of the mountain range (Akdim 2015). Data from the weather station at the site for 1971-2010 indicate a mean annual precipitation of $415 \mathrm{~mm}$ and mean annual temperature of $10.4^{\circ} \mathrm{C}$, with average temperatures of the coldest and warmest months (Jan, Aug) of $2.5^{\circ} \mathrm{C}$ and $19.7^{\circ} \mathrm{C}$, respectively (Sayad et al. 2011). Mountain ridges forms the south-eastern and northern margins of the lake, with open to semi-dense forest cover. The site lies within the montaneMediterranean bioclimate, and the dominant arboreal taxa at the site are Cedrus atlantica, Quercus rotundifolia and Juniperus thurifera. The forest cover around Sidi Ali is degraded by commercial logging, cutting for firewood, and grazing pressure. The cedar population at Sidi Ali, which includes individuals of $>900 \mathrm{yr}$ in age (Copes-Gerbitz, unpublished dendrochronological data), shows signs of extensive senescence and dieback. Restoration efforts including planting of seedlings are underway, but there does not appear to be widespread success of young trees in the area. The surrounding vegetation is a mix of scrub and forest (Morgan 1982; Lecompte 1986) (Figure 2d-f). A wide range of 
Author's Accepted Manuscript - Bell \& Fletcher (2016). Modern surface pollen assemblages from the Middle and High Atlas, Morocco: Insights into pollen representation and transport. Grana, 55:4, 286-301. Available online:

https://doi.org/10.1080/00173134.2015.1108996

woody taxa can be observed around Sidi Ali, including Ribes uva-crispa L., Rosa spp. and Berberis hispanica along the rocky lake margins, spiny cushion-form shrubs in open areas including Erinacea anthyllis, and a range of mesic tree taxa in the best preserved forest fragments on the north-facing slopes of the lake's southern margin. These latter include Acer monspessulanum L., Crataegus lacciniata Steven ex Besser and Fraxinus dimorpha Coss. \& Dureiu. The lake is a popular tourist spot and the area is subject to extensive animal grazing.
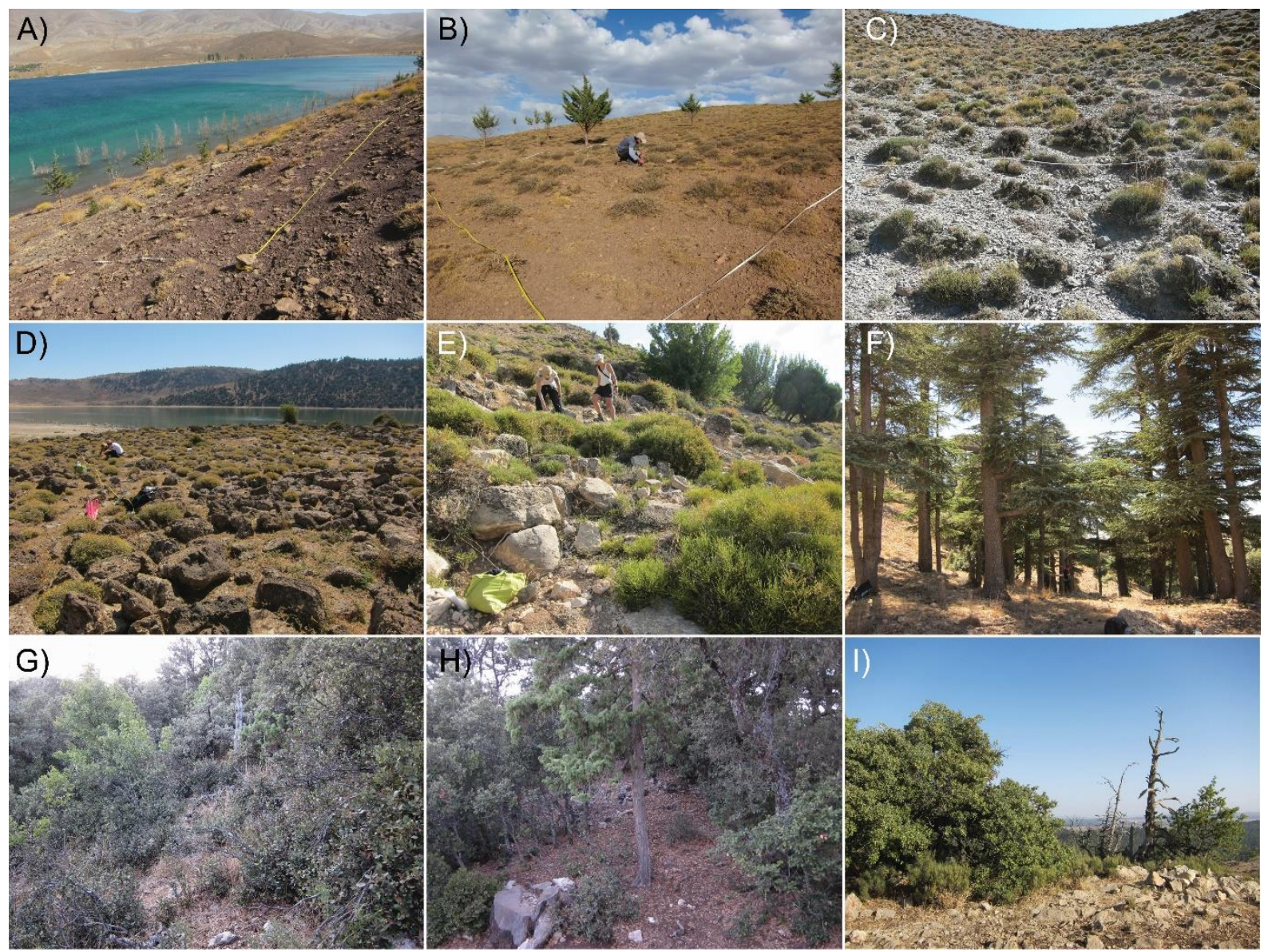

Figure 2. Sample site photos showing typical environmental setting and vegetation. A. TIS $01 \mathrm{~B}$. TIS 07 C. TIS 12 D. ALI 01 E. ALI 07 F. ALI 11 G. MICH 01 H. MICH 02 I. MICH 03.

Middle Atlas: Michliffen. - The second Middle Atlas study site (MICH) is located in the Michliffen caldera at $33^{\circ} 32^{\prime} \mathrm{N}, 5^{\circ} 6^{\prime} \mathrm{W}$ ( $2000 \mathrm{~m}$ a.s.l.), and $40 \mathrm{~km}$ to the north of Sidi Ali. The caldera is one of several extinct Plio-Pleistocene volcanoes in the northern plateaux of the Middle Atlas (Waele and Melis 2008). Climate at Ifrane, located $13 \mathrm{~km}$ to the north of Michliffen is characterised by mean annual precipitation of $900 \mathrm{~mm}$, mean annual temperature of $11.4^{\circ} \mathrm{C}$, and mean January (August) temperatures of $4^{\circ} \mathrm{C}\left(21.4^{\circ} \mathrm{C}\right)$. Michliffen is a popular touristic destination with a small ski resort, but retains a healthy forest cover (Figure $2 \mathrm{~g}-\mathrm{i}$ ), as well as a population of the emblematic Barbary 
Author's Accepted Manuscript - Bell \& Fletcher (2016). Modern surface pollen assemblages from the Middle and High Atlas, Morocco: Insights into pollen representation and transport. Grana, 55:4, 286-301. Available online:

https://doi.org/10.1080/00173134.2015.1108996

macacques (Macaca sylvanus). The southern-facing caldera slopes are covered by a montane Mediterranean mixed needle leaf-broadleaf forest with Cedrus atlantica and Quercus rotundifolia, with other taxa including Acer monspessulanum and Juniperus oxycedrus L.. The northern-facing slopes are dominated by stands of Cedrus atlantica.

\section{Field Sampling}

Soil surface samples were collected from 33 sites across the study locations in $10 \times 10$ m quadrats. Five evenly spaced subsamples (x-pattern) were taken from each quadrat from the top soil $(5 \mathrm{~mm}$ depth) and leaf litter and combined following Adam and Mehringer (1975) so as to ensure a wellmixed sample representing an integrated signal of the local pollen rain over the $100 \mathrm{~m}^{2}$ sampling area and several pollination seasons. Vegetation found in each quadrat was recorded as a presence/absence survey (Supplementary File 1), and visual estimates of ground cover and canopy cover recorded (Table 1). It should be noted that due to sampling in September, many annual species and cryptophytes may not have been visible. Detailed taxonomic identifications were also hindered by the lack of flowering at this time and heavy grazing impact.

In the High Atlas, samples were collected around the margins of Lake Tislit (TIS 1-10) at altitudes between 2250 - $2280 \mathrm{~m}$, and along an altitudinal transect (TIS 11-16) extending towards the north and reaching up to $2670 \mathrm{~m}$ (Figure 1c). The sampling locations were generally characterised by low vegetation cover and thin, xeric soils with sparse leaf litter (Table 1). Middle Atlas samples ALI 01-07 are located around the western and southern margins of the Lake Sidi Ali at $2090 \mathrm{~m}$ elevation in areas of open, scrubby vegetation, on basaltic substrates with sandy soils (ALI01-05) or on rocky soils on calcareous substrates (ALI 06-07). Samples ALI 08-14 are located in the forested area to the south of the lake at higher elevations between 2180 - $2200 \mathrm{~m}$ a.s.l. on calcareous substrates (Figure 1d). The three MICH sample sites span the lower slopes (MICH01, $1935 \mathrm{~m}$ a.s.l.) to ridge summit (MICH 03, $2088 \mathrm{~m}$ a.s.l.) (Figure 1e).

\section{Laboratory methods}

Organic matter was calculated using loss-on-ignition for each sample following Dean (1974). Preweighed samples were dried overnight at $105^{\circ} \mathrm{C}$, weighed, then fired at $550^{\circ} \mathrm{C}$ for 3 hours and further weighed to calculate organic matter content as a percentage of dry weight. 
Author's Accepted Manuscript - Bell \& Fletcher (2016). Modern surface pollen assemblages from the Middle and High Atlas, Morocco: Insights into pollen representation and transport. Grana, 55:4, 286-301. Available online:

https://doi.org/10.1080/00173134.2015.1108996

Table 1. Sample site location data including latitude and longitude, altitude, soil substrate, and estimates of ground and canopy cover.

\begin{tabular}{|c|c|c|c|c|c|c|}
\hline Site & Latitude & Longitude & Altitude & Substrate & $\begin{array}{l}\text { Ground } \\
\text { Cover }\end{array}$ & $\begin{array}{l}\text { Canopy } \\
\text { Cover }\end{array}$ \\
\hline TIS 01 & 32.19253 & -5.63389 & 2275 & Hillslope xeric soil on weathered mudstones & 5 & 0 \\
\hline TIS 02 & 32.19301 & -5.6329 & 2279 & Hillslope xeric soil on weathered mudstones & 15 & 0 \\
\hline TIS 03 & 32.19331 & -5.63222 & 2280 & Hillslope xeric soil on weathered mudstones & 15 & 0 \\
\hline TIS 04 & 32.19367 & -5.63142 & 2282 & Hillslope xeric soil on weathered mudstones & 10 & 0 \\
\hline TIS 05 & 32.19408 & -5.63063 & 2284 & Hillslope xeric soil on weathered mudstones & 15 & 0 \\
\hline TIS 06 & 32.1948 & -5.63002 & 2265 & Hillslope xeric soil on weathered mudstones & 15 & 0 \\
\hline TIS 07 & 32.19553 & -5.62895 & 2268 & Hillslope xeric soil on weathered mudstones & 20 & 0 \\
\hline TIS 08 & 32.19681 & -5.6289 & 2251 & Silty soil on lake shore sediments & 95 & 0 \\
\hline TIS 09 & 32.19977 & -5.62894 & 2282 & Hillslope xeric soil on weathered mudstones & 15 & 0 \\
\hline TIS 10 & 32.19984 & -5.63752 & 2260 & Alluvial fan & 25 & 0 \\
\hline TIS 11 & 32.20404 & -5.63877 & 2305 & Alluvial fan & 10 & 0 \\
\hline TIS 12 & 32.20866 & -5.63808 & 2363 & Xeric soil with loose stone cover & 40 & 0 \\
\hline TIS 13 & 32.21254 & -5.63794 & 2464 & Xeric soil with loose stone cover & 20 & 0 \\
\hline TIS 14 & 32.21563 & -5.6382 & 2561 & Xeric soil with loose stone cover & 20 & 0 \\
\hline TIS 15 & 32.2174 & -5.63739 & 2670 & Xeric soil with loose stone cover & 10 & 0 \\
\hline TIS 16 & 32.2185 & -5.64466 & 2760 & Angular rock field & 20 & 0 \\
\hline ALI 01 & 33.07393 & -5.00434 & 2095 & Basalt rocks, fine sands and silts & 35 & 0 \\
\hline ALI 02 & 33.07358 & -5.00493 & 2089 & Basalt boulder field, silty soil & 10 & 0 \\
\hline ALI 03 & 33.066 & -5.00717 & 2093 & Fine sand and silt & 20 & 0 \\
\hline ALI 04 & 33.06556 & -5.00742 & 2094 & Basaltic boulder field with aeolian sands & 50 & 40 \\
\hline ALI 05 & 33.06579 & -5.00715 & 2092 & Basaltic boulder field with aeolian sands & 25 & 5 \\
\hline ALI 06 & 33.06621 & -4.9989 & 2089 & Rocky limestone slope with silty soil & 40 & 10 \\
\hline ALI 07 & 33.06575 & -5.00133 & 2087 & Rocky calcareous slope with silty soil & 35 & 5 \\
\hline ALI 08 & 33.07024 & -4.98935 & 2180 & $\begin{array}{l}\text { Calcareous rocky slop with light organic soil } \\
\text { Calcareous rocky slop with light organic soil; }\end{array}$ & 60 & 20 \\
\hline ALI 09 & 33.07006 & -4.98992 & 2178 & $\begin{array}{l}\text { disturbed ground } \\
\text { Calcareous rocky slop with organic brown soil }\end{array}$ & 15 & 25 \\
\hline ALI 10 & 33.0696 & -4.99097 & 2179 & $\begin{array}{l}\text { and thick }(5 \mathrm{~cm}) \text { leaf litter } \\
\text { Calcareous rocky slope with stony cover and }\end{array}$ & 5 & 70 \\
\hline ALI 11 & 33.06909 & -4.99119 & 2184 & $\begin{array}{l}\text { gritty soil with leaf litter } \\
\text { Rocky calcareous slope with loose soil and stone } \\
\text { cover; abundant dead wood and disturbed }\end{array}$ & 20 & 55 \\
\hline ALI 12 & 33.06819 & -4.99185 & 2211 & $\begin{array}{l}\text { ground } \\
\text { Rocky, calcareous slope with light organic soil }\end{array}$ & 20 & 5 \\
\hline ALI 13 & 33.0675 & -4.99327 & 2191 & $\begin{array}{l}\text { and woody leaf litter } \\
\text { Rocky, calcareous slope with thin organic soil on }\end{array}$ & 10 & 15 \\
\hline ALI 14 & 33.06724 & -4.99372 & 2179 & $\begin{array}{l}\text { weathered bedrock with leaf litter } \\
\text { Calcareous soil on rocky substrate with organic }\end{array}$ & 60 & 20 \\
\hline MICH 01 & 33.41566 & -5.0792 & 1935 & $\begin{array}{l}\text { leaf litter } \\
\text { Calcareous soil on outcropping limestone with }\end{array}$ & 90 & 60 \\
\hline $\mathrm{MICH} 02$ & 33.41645 & -5.07991 & 1971 & light, organic rich soil & 40 & 80 \\
\hline MICH 03 & 33.4108 & -5.08487 & 2088 & Fine organic soil, rocky limestone & 30 & 15 \\
\hline
\end{tabular}


Author's Accepted Manuscript - Bell \& Fletcher (2016). Modern surface pollen assemblages from the Middle and High Atlas, Morocco: Insights into pollen representation and transport. Grana, 55:4, 286-301. Available online:

https://doi.org/10.1080/00173134.2015.1108996

Pollen samples were prepared from subsamples of $1 \mathrm{~cm}^{3}$ material following standard acetolysis preparation techniques (Erdtman 1960; Moore et al. 1991). Additionally dense-media-separation using sodium polytungstate (SPT) was used due to the high minerogenic sediments within the samples (Nakagawa et al. 2008). Lycopodium marker tablets were added to each sample to allow for absolute pollen analysis (Stockmarr 1971). Pollen was counted under a high power Zeiss microscope at $400 \mathrm{x}$ and $1000 \mathrm{x}$ magnification. Reference material (Reille 1992a; Reille 1995; Beug 2004; Liu et al. 2007) and sample slides held by The University of Manchester Geography Department were used for identification. Count sizes were between 303 and 643 grains (mean $=356$ ) with 52 taxa identified. Pollen percentages for plotting in the pollen diagram were calculated against a main sum of all taxa excluding degraded and unidentifiable grains (Supplementary File 2). Correspondence Analysis (CA) (e.g. Hill, 1973), a method for indirect gradient analysis suitable for datasets where large environmental gradients are anticipated, was performed on the untransformed pollen percentage dataset for taxa occurring at least once above a $5 \%$ threshold. Asteraceae, Fabaceae, Caryophyllaceae and Plantago sub-types were grouped for the analysis. Statistics were calculated using PAST (Hammer et al. 2001). Comparative pollen data for the central Moroccan region corresponding to Figure 1b was downloaded from the EMPD (Davis et al., 2013) and digitised from the main pollen diagram of SB91, corresponding to a total of 89 surface samples within the study region. For the purposes of comparison, averages of the assemblages for TIS, ALI and MICH samples, respectively, were calculated.

\section{Results}

\section{Characteristics of the soil surface samples}

Total organic content of the surface samples ranges from $<4 \%$ to $22 \%$ in the High Atlas, and $12 \%$ to $61 \%$ in the Middle Atlas; total pollen content of the surface samples ranges from $1.1 \times 10^{4}-4.7 \times 10^{5}$ grains per $\mathrm{cm}^{3}$ (Figure 3 ). The surface samples are highly minerogenic with low concentrations of pollen in the Tislit area and in open areas near Sidi Ali, and are richer in organic content with higher pollen concentrations in wooded areas of Sidi Ali and Michliffen. Overall, pollen concentration is positively correlated $(R=0.76, p<0.001)$ with the total organic matter content of the samples, as well as with canopy cover in the $10 \times 10 \mathrm{~m}$ sampling frame $(R=0.63, p<0.001)$. 


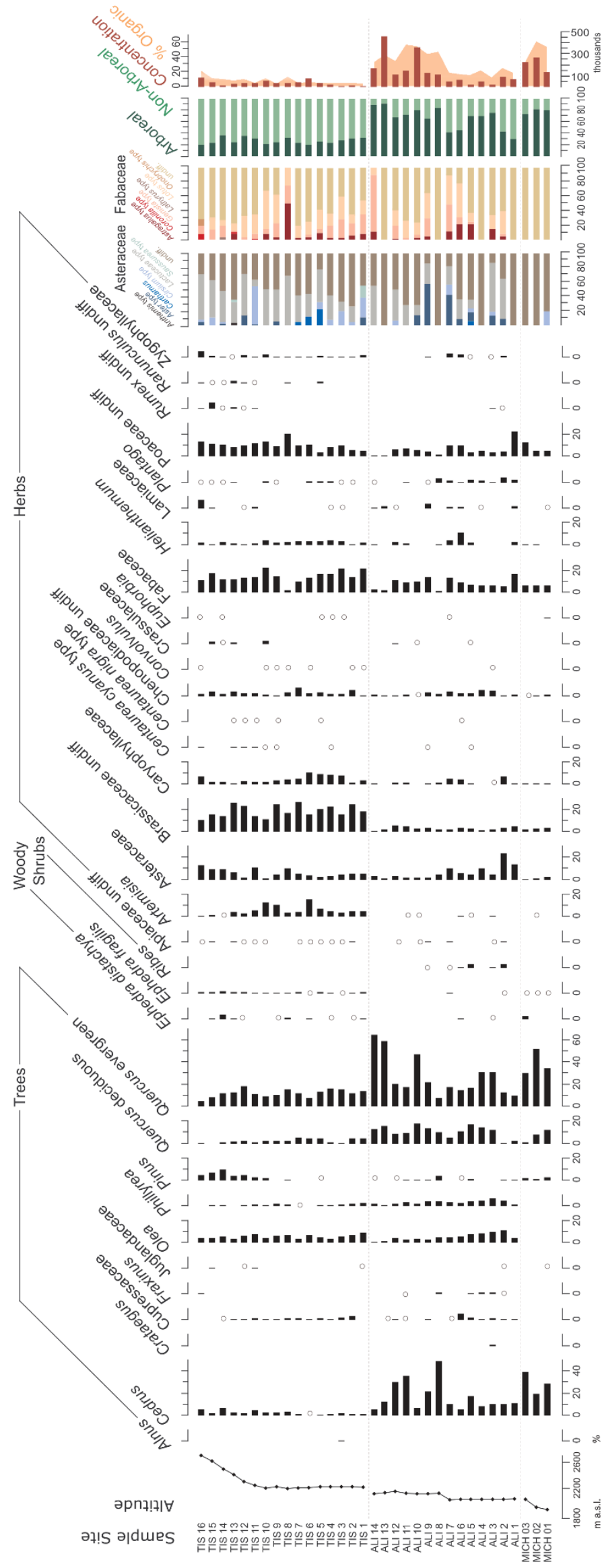

Figure 3. Pollen diagram showing percentage of pollen found for each taxa at each sampling location. Pollen below $0.5 \%$ is indicated by an open circle. Total pollen concentration and percentage organic matter is also shown. 
Author's Accepted Manuscript - Bell \& Fletcher (2016). Modern surface pollen assemblages from the Middle and High Atlas, Morocco: Insights into pollen representation and transport. Grana, 55:4, 286-301. Available online:

https://doi.org/10.1080/00173134.2015.1108996

\section{Characteristics of the pollen spectra}

Concerning arboreal pollen types, Cedrus pollen is detected in almost all samples at abundances $>1 \%$. Abundances are higher in $\mathrm{ALI}$ and $\mathrm{MICH}$ samples, reaching up to $50 \%$ under Cedrus canopy cover at ALI, while values do not exceed 7\% in any TIS sample. Cupressaceae (including Juniperus pollen) appears poorly represented in the pollen spectra at both locations (typically $\sim 1 \%$ ), despite being locally present and regionally significant at all sites. Olea is noteworthy for being detected in virtually all TIS and ALI samples (values up to $12 \%$ ), despite not growing locally and being typical of lower altitude bioclimatic stages. Similarly, Phillyrea is present in most ALI samples, but not TIS or $\mathrm{MICH}$. Pinus is not well represented in the pollen spectra, with the exception of TIS samples from the slopes above Lake Tislit, where abundances up to $10 \%$ are detected. The deciduous Quercus type is documented in almost all samples, with higher (>10\%) values in ALI samples. The evergreen Quercus type is detected in all samples, with TIS values less than $20 \%$ and ranging up to $40-60 \%$ in the ALI and $\mathrm{MICH}$ spectra. Ephedra types, typical of rocky terrain, are generally represented in low abundances, with more in the TIS spectra (up to 5\%) as compared to the ALI (<1\%) and $\mathrm{MICH}(<3 \%)$ spectra. Ribes, typical of the rocky margins of Lake Sidi Ali, is detected in low abundances in the ALI spectra (<4\%). Among other rare arboreal taxa, occasional grains of Juglandaceae are recorded across the sites (TIS 01, 11, 12, 16 and ALI 20,14), and Alnus and Crataegus occur in one sample each (TIS 03 and ALI 03, respectively).

Concerning non-arboreal pollen types, Artemisia occurs in values up to $\sim 15 \%$, with the higher abundances characteristic of the TIS spectra. Brassicaceae, Caryophyllaceae and Poaceae pollen types are virtually ubiquitous, but generally occur in higher abundances (up to $25 \%, 10 \%$, 20\% respectively) in the TIS spectra. Chenopodiaceae pollen is detected in almost all spectra, but at consistently low abundances $(<8 \%)$. Fabaceae pollen is well represented in most of the spectra, reaching values up to $20 \%$, with higher abundances in the TIS spectra, generally. While many of the Fabaceae grains were only identified to family level, Astragalus, Coronilla and Genista types (following Beug 2004) are well represented (Figure 2). Helianthemum pollen is generally detected in low abundances only, but is more common in the TIS spectra than in the ALI or MICH spectra; similar patterns are observed for Centaurea cyanus and C. nigra types. A number of other pollen types, including Crassulaceae, Rumex and Zygophyllaceae are detected sporadically in low abundances in the spectra. 
Author's Accepted Manuscript - Bell \& Fletcher (2016). Modern surface pollen assemblages from the Middle and High Atlas, Morocco: Insights into pollen representation and transport. Grana, 55:4, 286-301. Available online:

https://doi.org/10.1080/00173134.2015.1108996

\section{Local variability in pollen spectra}

While the TIS spectra are broadly homogeneous, there are subtle contrasts between the near-lake (low elevation) samples (TIS 01-10) and the higher slope samples (TIS 11-16). Artemisia and Caryophyllaceae are better represented in the near-lake samples, along with grazing-indicators Helianthemum and Plantago. There are also minor abundances of Cupressaceae consistent with local presence of junipers. In contrast, Asteraceae and, to a lesser extent, Poaceae are more abundant on the higher altitude slopes, along with higher abundances of extralocal to regional arboreal taxa (Cedrus and Pinus).

ALI samples display stronger contrasts between open, scrub and wooded areas with higher abundances of the dominant arboreal taxa Cedrus and Quercus evergreen in the wooded areas. Cupressaceae, although well represented in the local vegetation is poorly represented in the pollen spectra reaching only $6 \%$ in sample ALI 06 . Olea and Phillyrea both non-local taxa reach highest abundances in the open areas. Ribes is distinctive to the open areas, but is poorly represented overall with $\sim 4 \%$ in only 2 of the samples. Asteraceae is much more important in the open areas, along with Chenopodiaceae and Plantago. There is a large variation in total arboreal pollen (30-85\%) from scrub to closed canopy areas. $\mathrm{MICH}$ samples are dominated by arboreal types Cedrus and Quercus with some NAP (Fabaceae and Poaceae); however, clear patterns regarding spatial variability are not evident due to the smaller number of samples at this location.

\section{Discrimination between the study sites}

Sample and taxon scores on the first and second CA axes are shown in Figure 4. The combined axes account for $56 \%$ of the variance (Axis 1, eigenvalue $=0.2998,40.4 \%$; Axis 2, eigenvalue $=0.1194$, 16.1\%). Sample scores on Axis 1 are strongly correlated with AP\% $(R=0.983, p<0.0001)$ and effectively represents arboreal vegetation development, with positive scores for samples with higher AP. Axis 1 discriminates clearly between the TIS (oro-Mediterranean steppe) and Middle Atlas samples (ALI and $\mathrm{MICH}$, montane Mediterranean forest), with an intermediate cluster reflecting ALI sample sites with open vegetation characteristics. Sample scores on Axis 1 are also positively correlated with local canopy cover within the $10 \times 10$ m quadrats $(R=0.667, p<0.0001)$ and organic content of the surface soils $(R=0.862, p<0.0001)$.

Axis 2 discriminates primarily between Quercus- and Cedrus-rich samples from the Middle Atlas with positive scores for Quercus-rich samples, suggesting an influence of localised soil moisture availability, with positive scores for more drought tolerant and deeply rooted Quercus and negative 
scores for more moisture sensitive, shallow-rooting Cedrus species. However, environmental data to confirm this interpretation is not available. Axis 2 also reveals a significant altitudinal pattern, with more negative scores for higher altitude sites within the TIS cluster $(R=-0.86, p<0.0001)$, but not for the other study sites. Overall, this altitudinal pattern at TIS can be linked to higher abundances of Cedrus in the higher altitude TIS locations (especially TIS 11, 14-16). Overall, sample scores on Axis 2 appear unlikely to reflect a common environmental gradient, as the key taxon (Cedrus) is locally present at the Middle Atlas sites, but only present at part of a regional pollen rain at the TIS study site with source vegetation located $>30 \mathrm{~km}$ distant. The altitudinal discrimination of TIS sites on axis 2 therefore appears to reflect subtle contrasts in the relative contribution of local to regional pollen sources, perhaps linked to local productivity decreases with increasing altitude and a relatively greater contribution of pollen from distant sources.

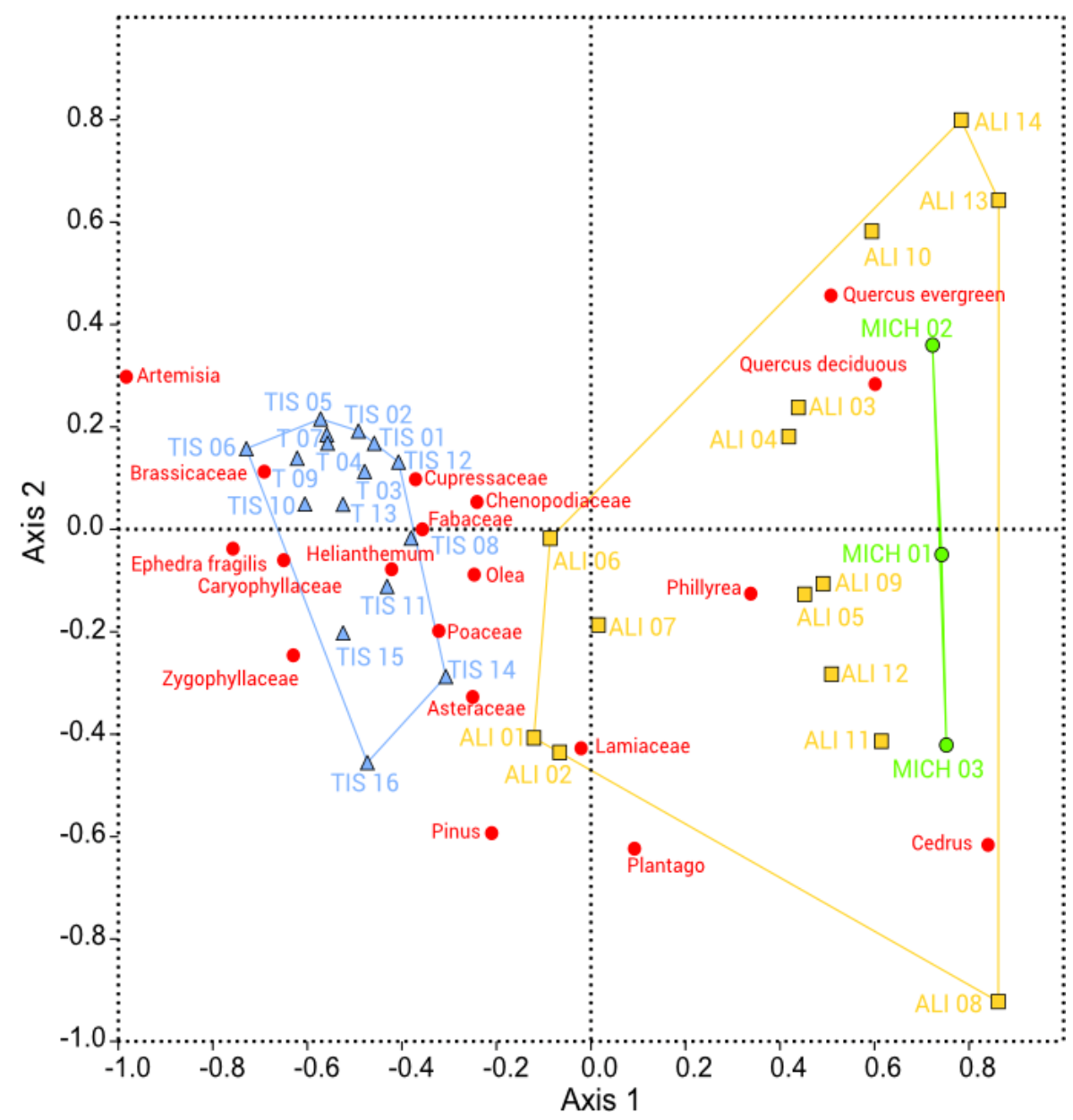

Figure 4. CA biplot of sample sites and key pollen taxa (those that occurred at $5 \%$ or more in at least one sample). Axis 1 accounts for $40.4 \%$ of the variance, effectively representing arboreal pollen abundance. Axis 2 accounts for $16.1 \%$ of the variance which has positive correlation with soil organic matter. 
Author's Accepted Manuscript - Bell \& Fletcher (2016). Modern surface pollen assemblages from the Middle and High Atlas, Morocco: Insights into pollen representation and transport. Grana, 55:4, 286-301. Available online: https://doi.org/10.1080/00173134.2015.1108996

The CA (Figure 4) shows High Atlas samples more closely grouped indicating less variability in the pollen spectra compared to the Middle Atlas samples. Species scores highlight the importance of non-arboreal taxa including Artemisia, Brassicaceae, Caryophyllaceae, Poaceae and Helianthemum in the TIS spectra, along with Cupressaceae. The Middle Atlas spectra (ALI and MICH) are distinguished by high abundances of Quercus (evergreen and deciduous type), Cedrus and Phillyrea. Sidi Ali samples are the most varied due to the more varied landscape (open scrub, forest) and indicate higher local-scale pollen variability. Michliffen spectra, which are dominated by AP, are separated by the dominance of either Quercus or Cedrus pollen, but fall within the range of ALI samples and are not clearly discriminated in the CA biplot.

\section{Discussion}

\section{Regional characterisation of the modern pollen rain}

Significant relationships between soil organic content, local canopy cover and pollen concentration point to a general linkage between vegetation cover type (open vs. wooded), soil and leaf litter organic content, and pollen concentration. These relationships may be linked to vegetation source effects, e.g. higher biomass, productivity and pollen production in forested environments vs. open environments, and/or to preservation factors associated with the more organic-rich surface soils and leaf litter layer (e.g. shading, moisture levels) developing under forest canopy. These latter factors are consistent with findings in other sedimentary contexts linking improved pollen preservation with higher organic content, e.g. marine sediments (Cheddadi and Rossignol-Strick, 1995).

The composition of the pollen samples shows meaningful differences across the different sampled environments, suggesting excellent potential for discrimination between different regional vegetation types from pollen spectra, either modern or ancient. In particular, the pollen spectra associated with the oro-Mediterranean steppic vegetation of the TIS study area are dominated by non-arboreal pollen types, especially Artemisia and other Asteraceae types, Brassicaceae, Poaceae, and Fabaceae, accompanied by Cupressaceae, Caryophyllaceae, Centaurea cyanus and nigra types, Convolvulus and Ephedra types. The pollen spectra of the montane Mediterranean Middle Atlas sites (ALI, MICH) in contrast are generally dominated by arboreal taxa (Cedrus and Quercus types) accompanied by Fraxinus and Ribes near Lake Sidi Ali. The first axis of the CA discriminates clearly between the High Atlas and Middle Atlas samples, reflecting primarily the contrasting importance of arboreal pollen type abundances across the sites. The main driver for differences reflected in axis 1 is likely to be macroclimatic contrasts between the study areas, in particular the combined influence on growing season moisture availability of higher precipitation and cooler summer temperatures in 
the Middle Atlas. Within the Middle Atlas samples, MICH samples and forested ALI samples are distinguished from more open, scrubby ALI sampling sites, partly reflecting higher precipitation at the $\mathrm{MICH}$ sites but also reflecting supplementary influences on arboreal cover at more localised scales (e.g. between ALI samples) of substrate type and/or grazing intensity.

\section{Insights into pollen dispersal and long-distance transport}

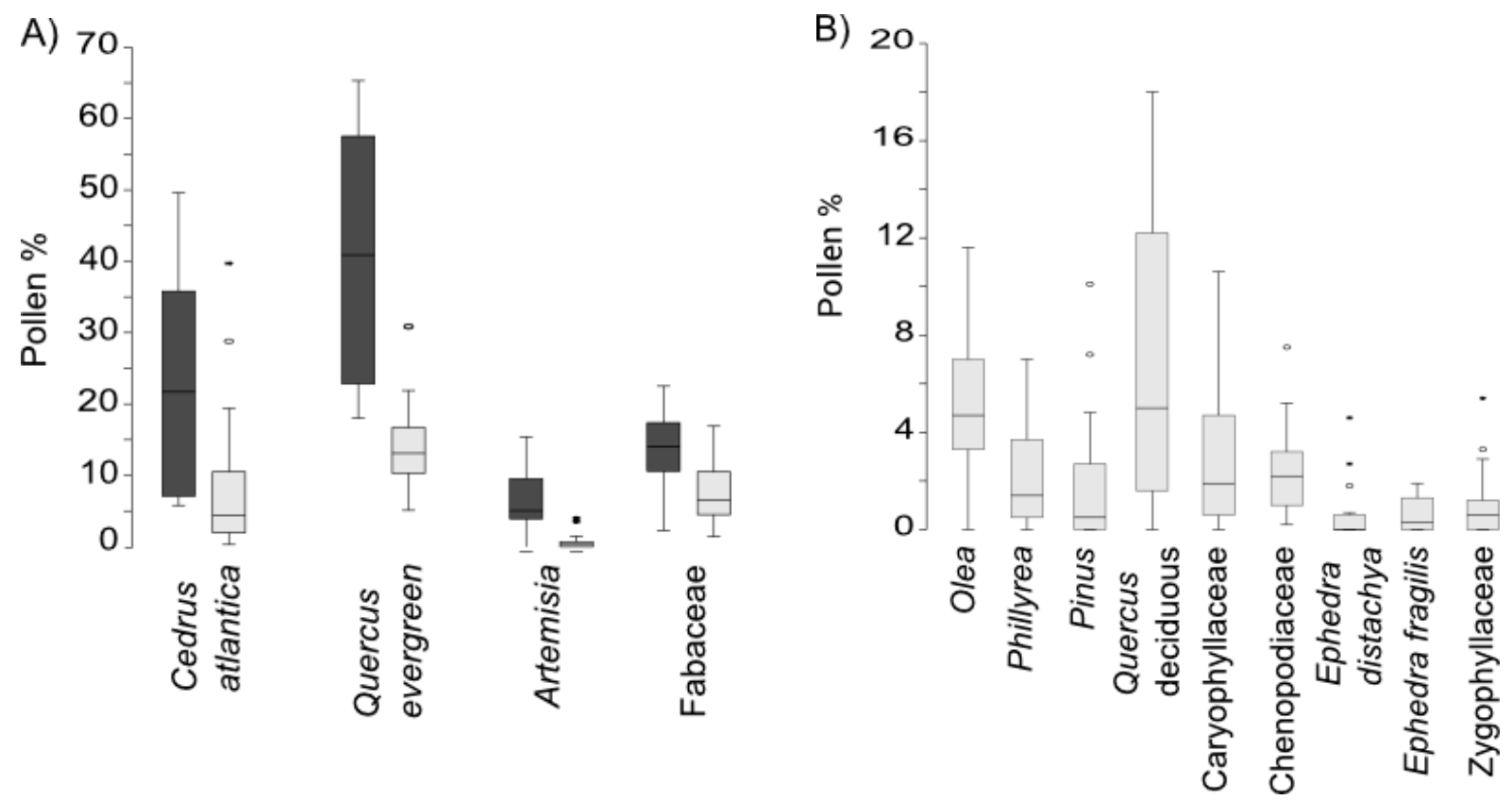

Figure 5. A: Box plots showing pollen abundance within a sample where source vegetation was recorded in one or more sampling quadrats (dark grey) verses pollen abundance found in samples where vegetation was not present (light grey) for indicated taxa. B: Box plots showing pollen abundance within a sample for indicated taxa where vegetation was not present in any sampling quadrats.

The comparison of the pollen spectra with the basic dataset resulting from the presence/absence survey (Appendix 1) highlights several taxon-specific patterns that may be important for the interpretation of regional ancient spectra. Here, we propose several taxon-specific hypotheses that are supported by our exploratory dataset and should be further tested using pollen traps and more extensive botanical surveys. Mann-Whitney tests showed that there was a significant difference $(P<0.05)$ for the indicated taxa (Figure 5$)$ between the pollen abundance observed where the vegetation was locally present in the quadrat, compared to pollen abundance where vegetation was absent. This comparison is of particular interest for large, woody taxa for which there is no uncertainty about their presence/absence within the quadrat (due to seasonal changes, grazing losses, etc.). 
Author's Accepted Manuscript - Bell \& Fletcher (2016). Modern surface pollen assemblages from the Middle and High Atlas, Morocco: Insights into pollen representation and transport. Grana, 55:4, 286-301. Available online: https://doi.org/10.1080/00173134.2015.1108996

Cedrus atlantica, a key forest taxon of considerable biogeographical and palaeoecological interest (Lamb et al. 1991; Cheddadi et al. 1998; Terrab et al. 2006; Fletcher and Goñi 2008; Cheddadi et al. 2009; Rhanem 2011) displays minor long-distance transport, being found as part of a regional pollen rain in the TIS samples in low abundances (typically $2.5 \%$ ). In the Middle Atlas, pollen abundances reach up to $50 \%$ (mean=19.2\%) in spectra from within pure or mixed Cedrus stands (ALI 08-14, MICH 01-03). Abundances in samples which lie only a few hundred metres from Cedrus trees (e.g. ALI 01-07) are considerably lower (typically 11\%). Overall, Cedrus pollen does not appear to be strongly dispersed, and our data suggests a threshold value of $~ 7 \%$ as indicative of local presence (Figure 4a). SB91 document similar low levels of Cedrus pollen outside the source regions, for example in the Mouloya Basin and pre-Saharan steppes. Our findings support their perspective and that of Salamani (1993), and Lamb and van der Kaars (1995), that Cedrus pollen is not well dispersed in the environment.

In areas near Cedrus stands (ALI 08-14, MICH 01-03) the average abundance of Cedrus is $25 \%$, but slightly higher in $\mathrm{MICH}$ samples (29.3\%) compared with the forested ALI samples (23.3\%). Although the difference is modest, other factors beside the abundance of Cedrus trees, such as pollen-production in response to moisture availability, may be affecting pollen abundance. Khanduri and Sharma (2009), for example, found a significant positive correlation between the number of pollen-producing strobili per branch of Cedrus deodara (Roxb. ex D.Don) G.Don and annual rainfall $(r=0.739, \mathrm{P}<0.01)$ in the Himalayas, and similar patterns may be anticipated for $C$. at lantica between the relatively humid $\mathrm{MICH}$ and dry ALI sites. It may also be a result of human caused degradation to the forest (stripping of branches for firewood) with qualitative observations suggesting this to be a more significant factor at the more degraded ALI sites compared to the relatively intact MICH sites.

Quercus evergreen pollen displays more important levels of long-distance transport, as it occurs in moderate abundances (average 14\%, up to 31\%) even where not locally present. The findings confirm that evergreen Quercus pollen is generally well dispersed in the study region (Lamb et al. 1989), including in the treeless TIS sector. Nevertheless, we observe that values greater than $20 \%$ predominantly occur in those samples where evergreen Quercus trees were recorded in the quadrat (Figure 4a), and therefore propose a threshold value for local presence for Quercus evergreen. This finding suggests that percentages below $\sim 20 \%$ must be interpreted with caution in vegetation reconstructions from ancient pollen spectra in the study regions.

Artemisia emerges as regionally distinctive taxon. Comparing spectra from sites with Artemisia vs sites without, an approximate threshold value of $\sim 4 \%$ for local presence is evident. It is 
Author's Accepted Manuscript - Bell \& Fletcher (2016). Modern surface pollen assemblages from the Middle and High Atlas, Morocco: Insights into pollen representation and transport. Grana, 55:4, 286-301. Available online: https://doi.org/10.1080/00173134.2015.1108996

noteworthy that total values for Artemisia are not especially high at any site in the present study, suggesting that regional analogues may not exist for the Artemisia rich assemblages of the Lateglacial and early Holocene in the Middle Atlas (e.g. Lamb et al. 1989). It is interesting to note that values of Artemisia in this study are much lower than those recorded by SB91; this difference may be due to a botanical focus in that study on areas with abundant Artemisia.

For Fabaceae pollen, a threshold for local presence of $10 \%$ is suggested by the data. Considering that this pollen type represents an entomophilous group of plants for which pollen dispersal may be poor, pollen abundances in both High and Middle Atlas locations are quite high (reaching $>20 \%$ ). However, the relatively high values and relationship with local presence highlight the significance of a local, gravity component near the source plants in the surface soil spectra that may not be as well-represented in other site/samples types (e.g. lake sediments, peat bogs). In contrast with the findings of Canellas-Bolta et al. (2009), who found Fabaceae to be a poor indicator of local presence in the Pyrenees, our findings suggest that variability in Fabaceae pollen may be significant in fossil spectra, with important implications for the detection of thorn-cushion vegetation cover and associated grazing pressures.

Several pollen types do not display significant differences associated with presence/absence in the quadrats, including Brassicaceae, Asteraceae (excluding Artemisia), Helianthemum, Poaceae, Lamiaceae and Plantago. These taxa do display inter-sample variability that may be related to local environmental factors (e.g. grazing pressure, soil moisture, etc.) for which data is not available. Detection of local presence may also be hindered by low visibility and representation of annual species in the survey.

Several key taxa were not recorded in the vegetation survey, but were documented in the pollen spectra (Figure 5b). Obviously, this can be due in part to issues of seasonal visibility, and that the sampling design will not account for taxa that may have been growing in close proximity to the quadrats but did not happen to fall with the sampling frame. However, some important insights emerge nevertheless. Quercus deciduous type pollen occurs in values up to $18 \%$. This pollen type most likely derives from deciduous and semi-deciduous oaks such as Quercus faginea and $Q$. pyrenaica growing at lower altitudes in the humid, supra-Mediterranean bioclimatic stage. For example, Q. faginea flourishes near Azrou at around $1600 \mathrm{~m}$ a.s.I.. Olea (and the closely related Phillyrea) is also widely detected in the spectra at values up to $12 \%$ and $7 \%$ respectively, despite not growing in the study regions. Olea is widespread in the thermo- and meso-Mediterranean stages, with extensive plantations around Meknes and Volubilis at $600 \mathrm{~m}$ elevation, for example. 
Author's Accepted Manuscript - Bell \& Fletcher (2016). Modern surface pollen assemblages from the Middle and High Atlas, Morocco: Insights into pollen representation and transport. Grana, 55:4, 286-301. Available online:

https://doi.org/10.1080/00173134.2015.1108996

Both Quercus deciduous type, Olea and Phillyrea appear to be widely dispersed beyond the source areas and over-represented at both the Middle Atlas locations and (excluding Phillyrea) in the High Atlas study site. In these cases, and in light of the broad distribution of vegetation formations at the wider regional scale, pollen transport would appear to derive from lower altitude zones to the $\mathrm{W}$ or NW. A similar upwind transport has been reported for Olea pollen in the Pyrenees, where it occurs consistently at low abundances in the sub-alpine and alpine zones (Canellas-Bolta et al. 2009).

Pinus is a well-known widely dispersed pollen producer (Erdtman 1943), and is found across the Middle and High Atlas, but does not form the dominant vegetation cover in any area near the study sites. Overall, Pinus pollen does not appear to be significantly over-represented at the study sites, in contrast with patterns in temperate or boreal latitudes. Pinus pollen deposition is principally detected on the southward-facing slopes above Lake Tislit (samples TIS 10-16) and at the eastern end of the lake (TIS 08,09 ) average $2.8 \%$, with highest value of $10.1 \%$ and TIS 14 . This pollen may be derived from the pine trees growing along the western shore of Lake Tislit. The absence of Pinus pollen in samples (TIS 01-07) suggests a complex local pattern with preferential pollen deposition to the $\mathrm{N}$ and NE of the source trees but not towards the E or SE possibly associated with local air currents. Pinus pollen is poorly represented in the Middle Atlas samples (average $0.9 \%$ ) and suggests a regional signal. The lower percentage may be a result of under-representation caused by the higher abundance of other arboreal pollen in these samples. Reille (1992b) found Pinus was to be under-represented in areas with mixed vegetation forests despite a wide distribution in Corsica, which would correspond with our findings.

Caryophyllaceae and Chenopodiaceae were not recorded at the sample locations, but are widely represented by many species in the study regions, including annual species that may not have been observed in the September field season. Similarly, Ephedra types were not locally present in the quadrats, but occur across the study regions. Zygophyllaceae pollen, possibly representing Zygophyllum and Fagonia spp., is more common in the TIS samples and is likely to reflect longdistance transport from low elevation desert regions.

Markgraf (1980), in a study of alpine vegetation in Switzerland, found that pollen productivity decreases as elevation increases, independent from plant density, such that higher elevation pollen spectra are more likely to reflect a regional signal carried from lowlands by prevailing wind conditions. In California, Soloman \& Silkworth (1986), found pollen deposition values to be high and variable near source plants, while lower, more uniform values were found at great distance from source. These observations are generally consistent with our findings. TIS samples 
have low pollen values with less variability, across the sampling locations for many of the nonpresent taxa (e.g. Cedrus, Quercus, Ephedra), while ALI samples show higher values with greater variability between sample locations where vegetation is present. This suggests that in the High Atlas, pollen abundance values in excess of the threshold values inferred in this study would be required to support local presence of anemophilous plants in the fossil record.

\section{Relationships between vegetation cover and arboreal pollen abundance}

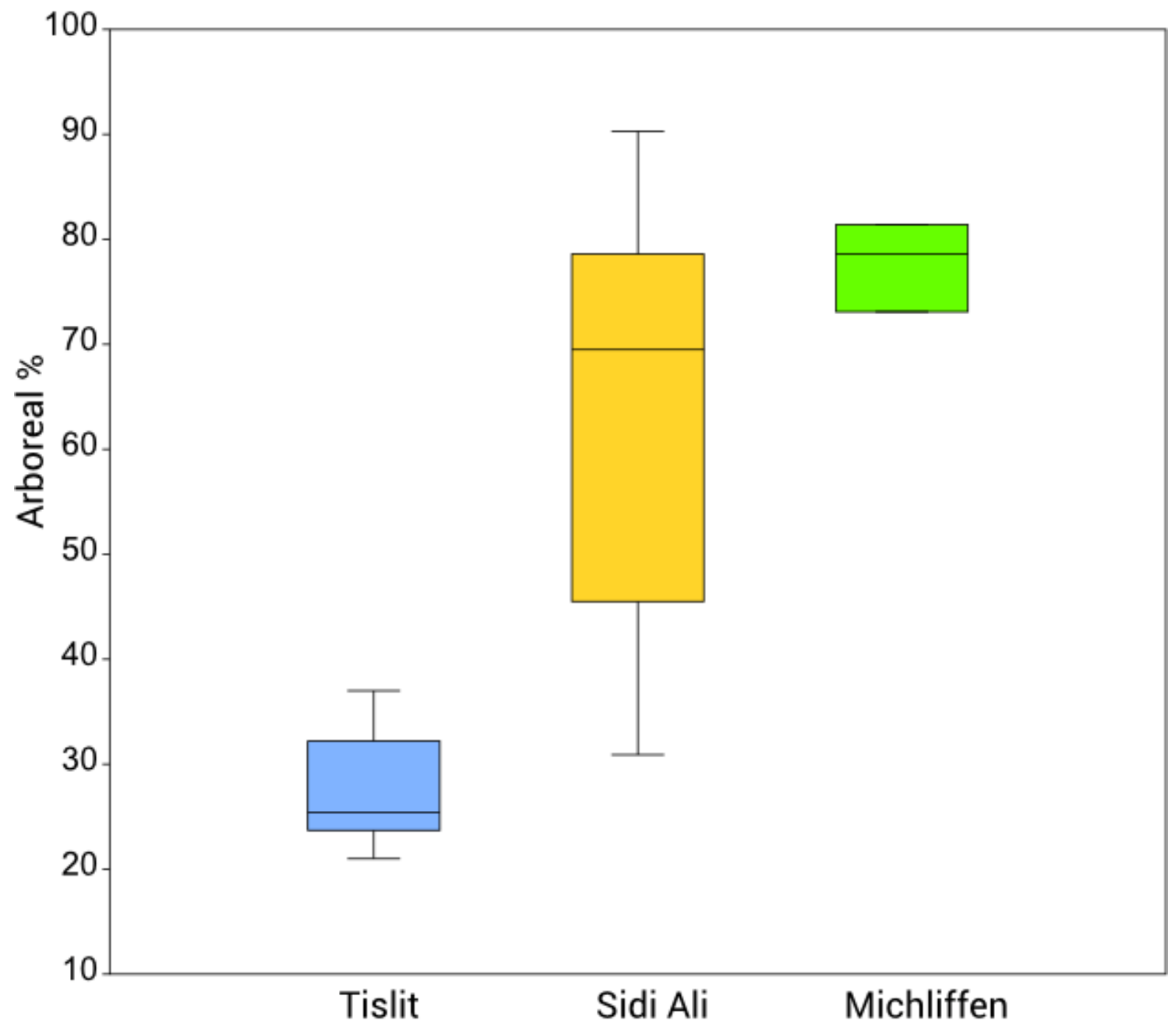

Figure 6. Box plot showing total arboreal pollen percentage at the sample sites grouped by sample location. 


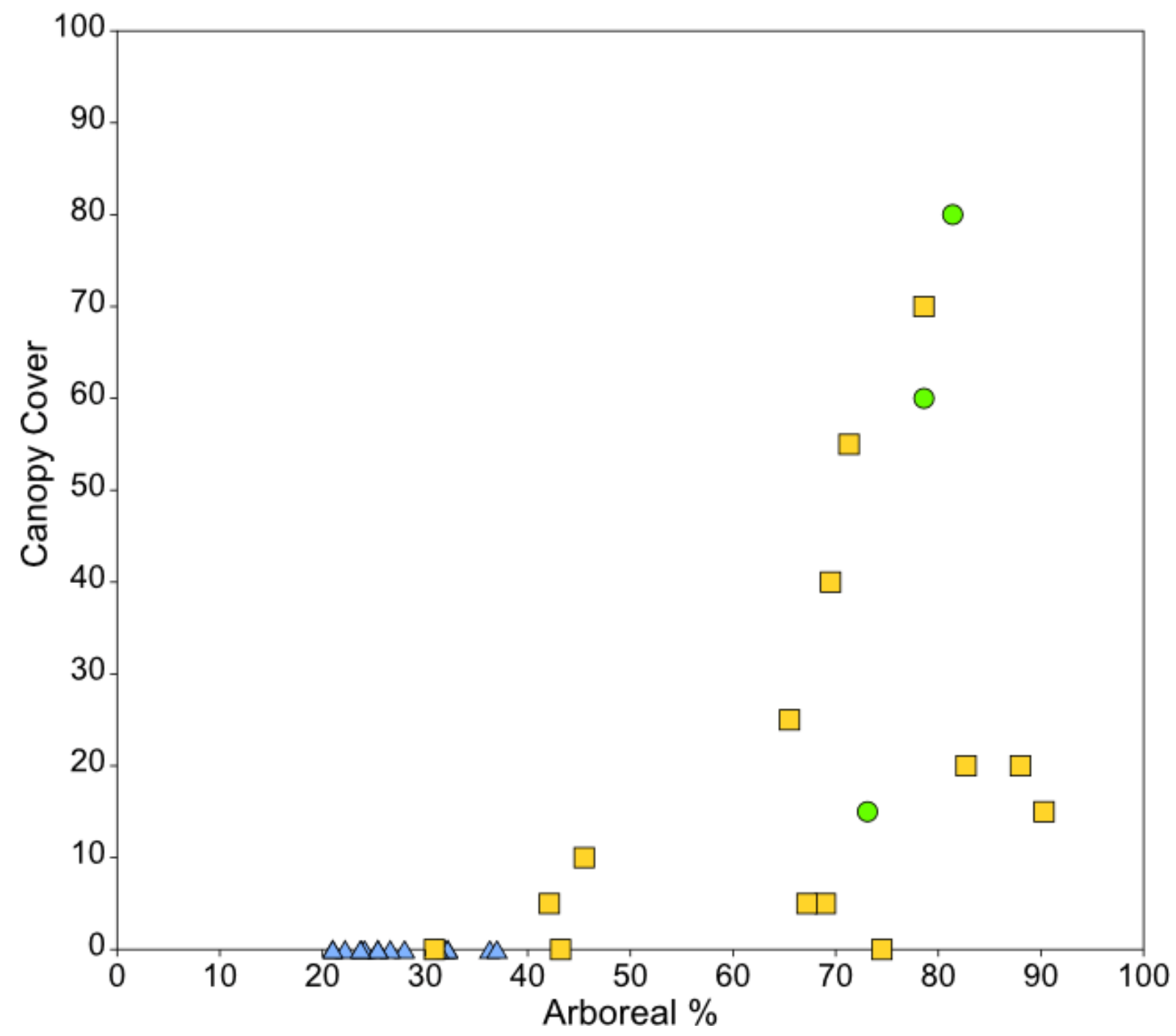

Figure 7. Plot of total arboreal pollen percentage verses canopy cover at the sample sites. Blue (online version) triangles represent Lake Tislit samples, yellow squares = Lake Sidi Ali samples, and green circles $=$ Michliffen samples. $(r=0.68, P<0.001)$.

Strong differentiation between the Tislit and Middle Atlas (ALI, MICH) spectra in terms of arboreal pollen abundance is evident, with values typically below $30 \%$ in the Tislit spectra (average $=27.6 \%$, s.d. $=5.2)$ and reaching up to $60-90 \%$ in the Sidi Ali $(a=65.6 \%$ s.d. $=18.3)$ and Michliffen $(a=77.7 \%$ s.d.=4.2) spectra (Figure 6). CA also confirms the importance of arboreal pollen abundance as the primary distinguishing characteristic of the pollen spectra across the study locations (Figure 3). In terms of potential for reconstruction of arboreal cover from AP\% values, we note a significant correlation between $(R=0.682, p<0.0001)$ between $A P \%$ and canopy cover estimates within the $10 \times 10 \mathrm{~m}$ quadrats (i.e. $100 \mathrm{~m}^{2}$ scale) (Figure 7). Observation of the associated scatterplot highlights several points. Arboreal pollen abundance attains values of $20-35 \%$ at TIS sites in the absence of 
Author's Accepted Manuscript - Bell \& Fletcher (2016). Modern surface pollen assemblages from the Middle and High Atlas, Morocco: Insights into pollen representation and transport. Grana, 55:4, 286-301. Available online:

https://doi.org/10.1080/00173134.2015.1108996

significant local or landscape-scale tree cover. These values, reflecting primarily Quercus types and Olea, highlight a significant regional to extra-regional airborne rain component, and reinforce the caution required for inferences regarding local presence of taxa in the open vegetation communities of the High Atlas. For sample locations with canopy cover greater than 20\% (i.e. forested ALI and $\mathrm{MICH}$ locations), arboreal pollen abundances increase in an approximately linear fashion with canopy cover. This suggests a close control on local soil pollen assemblages by the immediately surrounding vegetation, and dominance of gravity and trunk space pollen components (sensu Tauber 1965). At more open sampling locations at ALI and MICH with canopy cover up to $20 \%$, a very wide range of AP values are recorded (30-90\%). This suggests greater influence of wind-borne pollen (canopy and rain components (sensu Tauber 1965) from the surroundings in these more open sampling locations, consistent with higher abundances of extra-regional pollen (e.g. Olea and Phillyrea).

In summary, AP values of up to $35 \%$ are typical of open vegetation settings (TIS), values of 40-50\% occur in open sampling locations in the vicinity of forested areas (ALI 08-14), and values $>60 \%$ occur in forested areas (ALI, MICH). These values are consistent with previous observations in other Mediterranean settings (Wright et al. 1967; Bottema and Woldring 1990), and remain important for the interpretation of fossil spectra. The positive correlation between canopy cover at the scale of $100 \mathrm{~m}^{2}$ supports further investigations into relationships between arboreal pollen and arboreal vegetation cover at a wider range of spatial scales. In the future, this could include regionally-specific calibration of surface pollen spectra vs satellite imagery for reconstruction of arboreal cover (e.g. Jackson and Williams 2004).

\section{Comparison with archived surface sample data}

Figure 8 places the averaged data for TIS, ALI and MICH spectra in the wider geographical context of surface pollen data from the EMPD and SB91. This comparison reinforces many of the key observations made at the small spatial scale of intensive analysis at the TIS, ALI and MICH sites. For example, high values for Cedrus show a good match to proximity to the main vegetation source areas, reinforcing the inference of high values for this taxon being a reliable indicator for local proximity of source plants. Olea shows consistent abundances throughout the region regardless of distance to the main source areas to the northwest, confirming the extensive long-distance transport of this pollen-type. Pinus displays low values, highlighting that Pinus is not strongly overrepresented in regional pollen spectra, but rather reflects dispersal and mixing from small, localised pockets of vegetation cover scattered throughout the study region. 

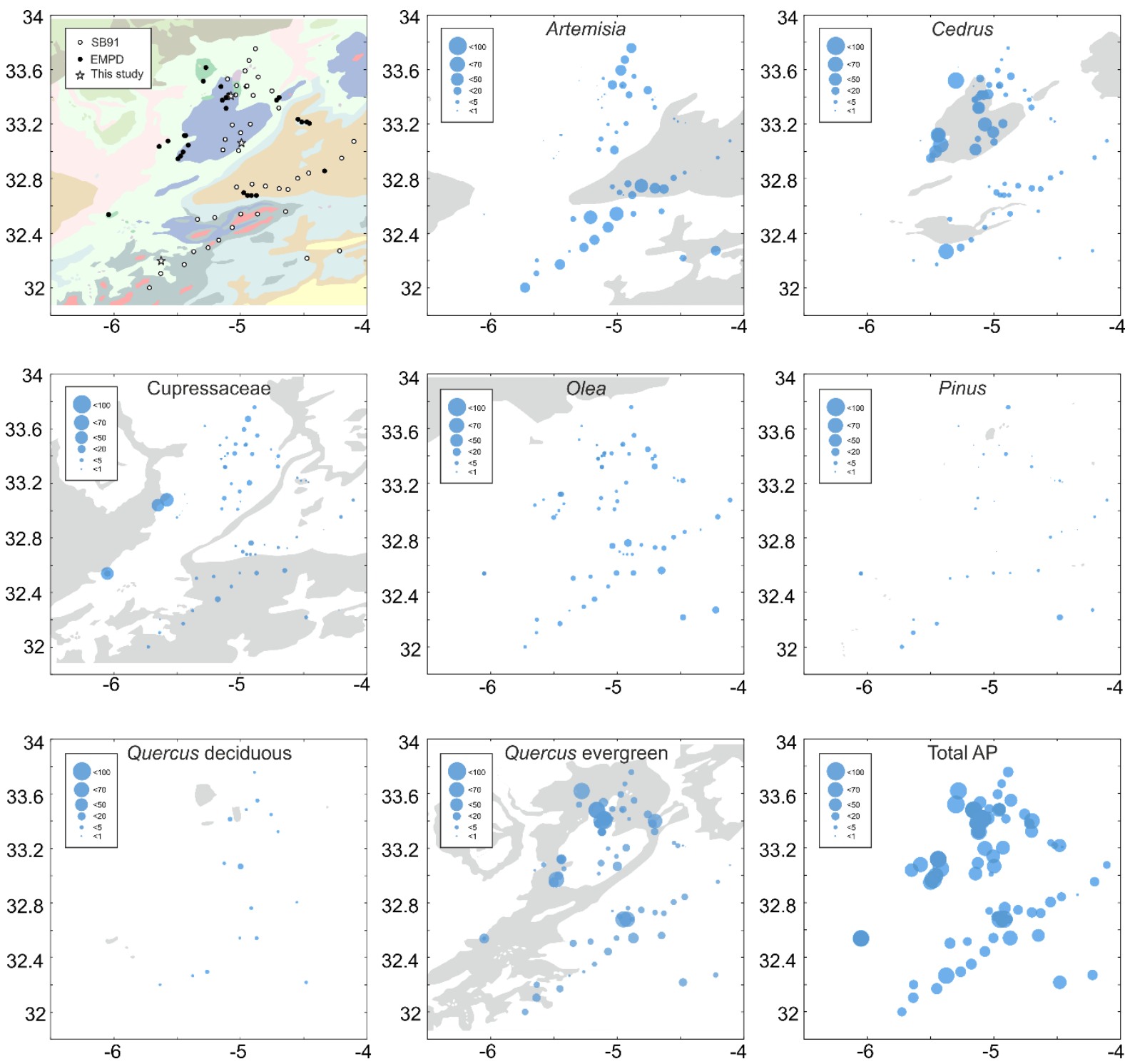

Figure 8. Bubble plots showing percentage of pollen from modern surface samples for indicated species. Location of corresponding vegetation cover shown in grey. EMPD = Data from the European Pollen Database (Davis et al. 2013). SB91 = Data digitised from Saadi and Bernard, (1991). Pollen data from this study shown here was averaged for each study area (TIS, ALI, MICH).

Cupressaceae, despite the ecological importance and wide distribution of source taxa (including Juniperus spp. and Tetraclinis articulata), are generally poorly represented in the regional spectra, with the exception of three samples in the western part of the study region, possibly indicating greater pollen productivity or dispersal from Tetraclinis. Quercus evergreen pollen occurs across all locations, but with highest values in the Middle Atlas near the dominant vegetation source areas. This pattern is consistent with the inference that this pollen type is widely dispersed but nevertheless may provide a reliable indicator of local presence when recorded at high abundances. 
Author's Accepted Manuscript - Bell \& Fletcher (2016). Modern surface pollen assemblages from the Middle and High Atlas, Morocco: Insights into pollen representation and transport. Grana, 55:4, 286-301. Available online:

https://doi.org/10.1080/00173134.2015.1108996

The deciduous Quercus pollen type is infrequently recorded in the archived datasets, but appears in low frequencies across the study region. Artemisia is generally recorded at higher values in the High Atlas and lower values in the Cedrus-dominated regions of the Middle Atlas, consistent with differences between the TIS, ALI and MICH samples. We note that the SB91 spectra generally record higher Artemisia abundances which may reflect a sampling strategy in that study focused on Artemisia communities. While the analysis supports many of the observations from the new datasets, we note a caveat that the dominant vegetation cover types derived from Emberger (1939) shown in Figure 8 do not represent species distribution ranges, and that the vegetation may have been significantly influenced by anthropogenic modification and climatic change during the 20th century.

\section{Conclusions}

Modern surface pollen assemblages can provide important insights into pollen production and dispersal at a range of spatial scales. In dry Mediterranean and semi-arid areas near the climatological limits of forest development, it is especially interesting to understand the relationships between tree cover and arboreal pollen abundances, as well as upwind altitudinal movement of pollen. In this study 33 new pollen spectra are reported from three oro-Mediterranean montane sites located between 1935 and 2760 m a.s.l. in the Middle and High Atlas, Morocco. As the study reflects an opportunistic/exploratory sampling strategy, key patterns emerging from the dataset should be considered as hypotheses meriting further testing. Discrimination between vegetation covers of the the High Atlas (TIS) and Middle Atlas (ALI, MICH) sites is possible (as highlighted, for example, by the Correspondence Analysis), primarily reflecting contrasting development of arboreal cover (especially Cedrus and evergreen Quercus). The High Atlas spectra are furthermore rich in non-arboreal taxa such as Artemisia, Brassicaceae, Caryophyllaceae and Fabaceae, and distinguished by noteworthy occurrences of Helianthemum, Centaurea cyanus and nigra types, and Ephedra types. Comparing the pollen spectra with presence/absence information from vegetation survey highlights taxa that can be considered as good indicators of local presence (Cedrus, evergreen Quercus, Artemisia, Fabaceae), taking into account threshold values of around $7 \%, 20 \%, 4 \%$ and $10 \%$, respectively, as indicative of local occurrence within the $10 \times 10 \mathrm{~m}$ quadrat. Our results highlight long-distance effects and upwind altitudinal transport of three taxa (deciduous Quercus, Olea, Phillyrea). Overall, the findings from this new data at the small spatial scale of the three study sites are supported at the wider regional scale by comparison with existing data from the EMPD and SB91. The insights from this study should be taken into account in the interpretation of ancient pollen spectra from lakes and bogs in the region. For improving the understanding of 
pollen production and transport vectors in Moroccan montane environments, several lines of investigation should prove fruitful, including additional surface studies across larger altitudinal ranges (e.g. Yu et al., 2001; Canellas-Bolta et al., 2009), nested botanical survey at varied spatial scales leading to quantitative determination of species-specific pollen production values (e.g. Broström et al. 2008), and evaluation of pollen spectra in lake surface sediments (e.g. Guimarães et al. 2014).

\section{Acknowledgements}

WF kindly acknowledges C. Zielhofer and S. Mischke Field and field support provided by German Science Foundation Pilot Research Grant “Late Quaternary geomorphological and environmental response to rapid hydrological cycles in the Atlas Mountains, Morocco" (DFG ZI 721/9-1). We gratefully acknowledge the assistance of Nick Scarle in Cartography at the School of Environment, Education and Development, (University of Manchester). We thank two anonymous reviewers for helpful comments that have improved the final manuscript.

\section{Supplementary Files}

Supplementary data mentioned in this manuscript (pollen assemblage data) can be downloaded from Mendeley Data, available at: http://dx.doi.org/10.17632/48ygt7bx7f.2 


\section{References}

Adam, D. P., \& Mehringer, P. J. J. (1975). Modern pollen surface samples--an analysis of subsamples. Journal Research, U.S.A. Geological Survey, 3, 733-736.

Akdim, B. (2015). Karst landscape and hydrology in Morocco: research trends and perspectives. Environmental Earth Sciences, 1-15.

Barrow, C. ., \& Hicham, H. (2000). Two complimentary and integrated land uses of the western High Atlas Mountains, Morocco: the potential for sustainable rural livelihoods. Applied Geography, 20(4), 369-394.

Beug, H. J. (2004). Leitfaden der Pollenbestimmung für Mitteleuropa und angrenzende Gebiete. Munich: Pfeil.

Bhattacharya, T., Beach, T., \& Wahl, D. (2011). An analysis of modern pollen rain from the Maya lowlands of northern Belize. Review of Palaeobotany and Palynology, 164(1-2), 109-120.

Born, K., Fink, A. H., \& Paeth, H. (2008). Dry and wet periods in the northwestern Maghreb for present day and future climate conditions. Meteorologische Zeitschrift, 17(5), 533-551.

Bottema, S., \& Woldring, H. (1990). Anthropogenic indicators in the pollen record 19 of the Eastern Mediterranean. In Man's Role in the Shaping of the Eastern Mediterranean Landscape: Proceedings of the Symposium on the Impact of Ancient Man on the Landscape of the E Med Region \& the Near East. Groningen: CRC Press.

Bradshaw, R. H. W. (1981). Modern pollen-representation factors for Woods in South-East England. Journal of Ecology, 69(1), 45-70.

Broström, A., Nielsen, A. B., Gaillard, M.-J., Hjelle, K., Mazier, F., Binney, H., ... Sugita, S. (2008). Pollen productivity estimates of key European plant taxa for quantitative reconstruction of past vegetation: a review. Vegetation History and Archaeobotany, 17(5), 461-478.

Canellas-Bolta, N., Rull, V., Vigo, J., \& Mercade, a. (2009). Modern pollen--vegetation relationships along an altitudinal transect in the central Pyrenees (southwestern Europe). The Holocene, 19(8), 1185-1200.

Chaabout, S., Chennaoui Aoudjehane, H., Reimold, W. U., Aboulahris, M., \& Aoudjehane, M. (2013). Evidence of Non-Impact Cratering Origin of Imilchil (Morocco) Lakes (Isli and Tislit). Large Meteorite Impacts and Planetary Evolution V.

Cheddadi, R., Fady, B., François, L., Hajar, L., Suc, J. P., Huang, K., ... Ortu, E. (2009). Putative glacial refugia of Cedrus atlantica deduced from Quaternary pollen records and modern genetic diversity. Journal of Biogeography, 36, 1361-1371.

Cheddadi, R., Lamb, H. F., Guiot, J., \& Van Der Kaars, S. (1998). Holocene climatic change in Morocco: A quantitative reconstruction from pollen data. Climate Dynamics, 14(12), 883-890. 
Cheddadi, R., \& Rossignol-Strick, M. (1995). Improved preservation of organic matter and pollen in eastern Mediterranean sapropels. Paleoceanography, 10(2), 301-309.

Davis, B. A. S., Zanon, M., Collins, P., Mauri, A., Bakker, J., Barboni, D., ... Kaplan, J. O. (2013). The European Modern Pollen Database (EMPD) project. Vegetation History and Archaeobotany, 22(6), 521-530.

Davis, K. O. (1984). Pollen frequencies reflect vegetation patterns in a great basin (U.S.A.) mountain range. Review of Palaeobotany and Palynology, 40(4), 295-315.

Davis, M. B., \& Goodlett, J. C. (1960). Comparison of the Present Vegetation with Pollen-Spectra in Surface Samples from Brownington Pond, Vermont. Ecology, 41(2), 346-357.

Dean, W. E. (1974). Determination of Carbonate and Organic-Matter in Calcareous Sediments and Sedimentary-Rocks by Loss on Ignition - Comparison with Other Methods. Journal of Sedimentary Petrology, 44(1), 242-248.

Emberger, L. (1939). Aperçu général sur la végétation du Maroc. Veröff. Geobot. Inst. Rübel Zürich, $14,40-157$.

Erdtman, G. (1943). An Introduction to Pollen Analysis. Massachusetts: The Chronica Botanica Company.

Erdtman, G. (1960). The acetolysis method. A revised description. Svensk Bot. Tidsk.

Faegri, K., \& Iversen, J. (1950). Text-book of modern pollen analysis. Geologiska Föreningen i Stockholm Förhandlingar 72(3).

Fall, P. L. (2012). Modern vegetation, pollen and climate relationships on the Mediterranean island of Cyprus. Review of Palaeobotany and Palynology, 185, 79-92.

Fink, A. H., Born, C. M., Bruecher, T., Piecha, K., Pohle, S., Schulz, O., \& Ermert, V. (2010). Impacts of Global Change on the Hydrological Cycle in West and Northwest Africa. In S. P, C. M, \& D. B (Eds.), Impacts of Global Change on the Hydrological Cycle in West and Northwest Africa. Heidelberg, Germany: Springer.

Fletcher, W., \& Goñi, M. (2008). Orbital-and sub-orbital-scale climate impacts on vegetation of the western Mediterranean basin over the last 48,000 yr. Quaternary Research 70(3), 451-464.

Gaillard, M.-J., Birks, H. J. B., Emanuelsson, U., Karlsson, S., Lagerås, P., \& Olausson, D. (1994). Application of modern pollen/land-use relationships to the interpretation of pollen diagramsreconstructions of land-use history in south Sweden, 3000-0 BP. Review of Palaeobotany and Palynology, 82(1-2), 47-73.

Giorgi, F. (2006). Climate change hot-spots. Geophysical Research Letters, 33(8), L08707.

Guimarães, J. J. T. F., Souza-Filho, P. P. W. M., Alves, R., de Souza, E. B., da Costa, F. R., Reis, L. S., ... Dall'Agnol, R. (2014). Source and distribution of pollen and spores in surface sediments of a plateau lake in southeastern Amazonia. Quaternary International, 352, 181-196. 
Hammer, Ø., Harper, D., \& Ryan, P. (2001). Past: Paleontological Statistics Software Package for education and data analysis. Palaeontologia Electronica, 4, 1-9.

Haroni, S. A. (2009). La diversité floristique des pelouses humides d'Altitude: cas de quelques sites du Haut Atlas Marocain. Acta Botánica Malacitana, 34, 91-106.

Hicks, S. (2001). The use of annual arboreal pollen deposition values for delimiting tree-lines in the landscape and exploring models of pollen dispersal. Review of Palaeobotany and Palynology, 117(1-3), 1-29.

Hirons, K. R. (1986). Numerical methods in quaternary pollen analysis. Journal of Archaeological Science (Vol. 13). Academic Press. Harcourt Brace Jovanovich.

Ibhi, A., Nachit, H., Abia, E. H., Touchnt, A. A., \& Vaccaro, C. (2013). Isli and Tislit: The First Dual Impact Crater Discovered in Morocco. International Journal of Astronomy and Astrophysics, 03(2), 1-4.

Jackson, S. T., \& Williams, J. W. (2004). MODERN ANALOGS IN QUATERNARY PALEOECOLOGY: Here Today, Gone Yesterday, Gone Tomorrow? Annual Review of Earth and Planetary Sciences, 32(1), 495-537.

Khanduri, V. P., \& Sharma, C. M. (2009). Cyclic pollen production in Cedrus deodara. Sexual Plant Reproduction, 22(2), 53-61.

Lamb, H., Eicher, U., \& Switsur, V. (1989). An 18,000-year record of vegetation, lake-level and climatic change from Tigalmamine, Middle Atlas, Morocco. Journal of Biogeography, 16(1), 6574.

Lamb, H. F., Damblon, F., \& Maxted, W. (1991). Human impact on the vegetation of the Middle Atlas, Morocco, during the last 5000 years. Journal of biogeography, 519-532.

Lamb, H. F., Duigan, C. A., Gee, J. H. R., Kelts, K., Lister, G., Maxted, R. W., ... Zeroual, E. (1994). Lacustrine Sedimentation in a High-Altitude, Semi-Arid Environment: The Palaeolimnological Record of Lake Isli, High Atlas, Morocco. In A. C. Millington \& K. Pye (Eds.), Environmental Change in Drylands: Biogeographical and Geomorphological Perspectives (pp. 147-161). John Wiley \& Sons Ltd.

Lamb, H. F., \& van der Kaars, S. (1995). Vegetational response to Holocene climatic change: pollen and palaeolimnological data from the Middle Atlas, Morocco. The Holocene, 5(4), 400-408.

Lamb, H., Roberts, N., Leng, M., Barker, P., Benkaddour, A., \& Van Der Kaars, S. (1999). Lake evolution in a semi-arid montane environment: Responses to catchment change and hydroclimatic variation. Journal of Paleolimnology, 21(3), 325-343.

Lecompte, M. (1986). Biogéographie de la montagne marocaine: le Moyen-Atlas central. Paris: Éditions du Centre National de la Recherche Scientifique. 
Liu, (Christopher) Yu-Sheng, Zetter, R., Ferguson, D. K., \& Mohr, B. A. R. (2007). Discriminating fossil evergreen and deciduous Quercus pollen: A case study from the Miocene of eastern China. Review of Palaeobotany and Palynology, 145(3-4), 289-303.

Markgraf, V., (1980). Pollen Dispersal in a Mountain Area. Grana 19, 127-146.

Moore, P. D., Webb, J. A., \& Collison, M. E. (1991). Pollen analysis. Blackwell Scientific Publications.

Morgan, N. C. (1982). An ecological survey of standing waters in North West Africa: II. Site descriptions for Tunisia and Algeria. Biological Conservation, 24(2), 83-113.

Nakagawa, T., Brugiapaglia, E., Digerfeldt, G., Reille, M., Beaulieu, J.-L. De, \& Yasuda, Y. (2008). Dense-media separation as a more efficient pollen extraction method for use with organic sediment/deposit samples: comparison with the conventional method. Boreas, 27(1), 15-24.

Navarro, T., Oualidi, J. El, \& Taleb, M. (2009). Dispersal traits and dispersal patterns in an oroMediterranean thorn cushion plant formation of the eastern High Atlas, Morocco. Flora: Morphology, Distribution, Functional Ecology of Plants, 204(9), 658-672.

Peyron, M. (1980). Les chutes de neige dans l'Atlas marocain. Revue de géographie alpine, 68(3), 237-254.

Prentice, I. C. (1985). Pollen representation, source area, and basin size: Toward a unified theory of pollen analysis. Quaternary Research, 23(1), 76-86.

Reille, M. (1992a). Pollen et spores d'Europe et d'Afrique du Nord. Marseille: Laboratoire de Botanique historique et Palynologie.

Reille, M. (1992b). New Pollen-Analytical Researches in Corsica - the Problem of Quercus-llex L and Erica-Arborea L; the Origin of Pinus-Halepensis Miller Forests. New Phytologist, 122(2), 359378.

Reille, M. (1995). Pollen et spores d'Europe et d'Afrique du Nord Supplement 1. Marseille: Laboratoire de Botanique historique et Palynologie.

Rhanem, M. (2011). Aridification du climat régional et remontée de la limite inférieure du cèdre de I'Atlas (Cedrus atlantica Manetti) aux confins de la plaine de Midelt (Maroc). Physio-Géo, 5, 143-165.

Ritchie, J. C. (1995). Current trends in studies of long-term plant community dynamics. New Phytologist, 130(4), 469-494.

Rognon, P. (1987). Late quaternary climatic reconstruction for the maghreb (North Africa). Palaeogeography, Palaeoclimatology, Palaeoecology, 58(1-2), 11-34.

Saadi, F., \& Bernard, J. (1991). Rapport entre la pluie pollinique actuelle, le climat et la végétation dans les steppes à Artemisia et les milieux limitrophes au Maroc. Palaeoecology of Africa and the Surrounding Islands. AA Balkema, Rotterdam, (22), 67-86. 
Salamani, M. (1993). Premières données paléophytogéographiques du cèdre de l'Atlas (Cedrus atlantica) dans la région de Grande Kabylie (NE Algérie). Palynosciences, 2, 123-130.

Sayad, A., Chakiri, S., Martin, C., Bejjaji, Z., \& Echarfaoui, H. (2011). Effet des conditions climatiques sur le niveau du lac Sidi Ali (Moyen Atlas, Maroc). Physio-Géo, 5, 251-268.

Solomon, A.M., Silkworth, A.B., (1986). Spatial patterns of atmospheric pollen transport in a montane region. Quaternary Research 25, 150-162.

Solomon, S., Plattner, G.-K., Knutti, R., \& Friedlingstein, P. (2009). Irreversible climate change due to carbon dioxide emissions. Proceedings of the National Academy of Sciences of the United States of America, 106(6), 1704-9.

Stockmarr, J. (1971). Tablets with spores used in absolute pollen analysis. Pollen et Spores. 13, 615621.

Sugita, S. (1994). A model of pollen source area for an entire basin. Review of Palaeobotany and Palynology. 82(1-2), 194.

Tauber, H. (1965). Differential pollen dispersion and the interpretation of pollen diagrams, with a contribution to the interpretation of the elm fall. Danmarks Geologiske Unders øgelse. Række 89(2).

Terrab, A., Paun, O., Talavera, S., Tremetsberger, K., Arista, M., \& Stuessy, T. F. (2006). Genetic diversity and population structure in natural populations of Moroccan Atlas cedar (Cedrus atlantica; Pinaceae) determined with cpSSR markers. American Journal of Botany, 93(9), 127480 .

Waele, J., \& Melis, M. T. (2008). Geomorphology and geomorphological heritage of the Ifrane-Azrou region (Middle Atlas, Morocco). Environmental Geology, 58(3), 587-599.

Wright, H. E. (1967). The use of surface samples in quaternary pollen analysis. Review of Palaeobotany and Palynology, 2(1-4), 321-330.

Wright, H. E., McAndrews, J., \& Zeist, W. van. (1967). Modern pollen rain in western Iran, and its relation to plant geography and Quaternary vegetational history. Journal of Ecology, J55(2), 415-443.

Yu, G. Tang, L. Yang, X., Ke, X. \& Harrison, S. P. (2001). Modern pollen samples from alpine vegetation on the Tibetan Plateau. Global Ecology and Biogeography, 10(5), 503-519. 